\title{
Üniversite Öğrencilerinin Evlilik Öncesi İlişkilerde Problem Yaşadıkları ve Eğitim Almak İstedikleri Konular*
}

\author{
Özlem HASKAN AVCI ${ }^{* *}$
}

\section{$\ddot{O} z$}

$\mathrm{Bu}$ çalışmanın amacı, üniversite öğrencilerinin romantik ilişkilerinde problem yaşadıkları alanlar; evlendikten sonra problem yaşayacaklarını düşündükleri alanlar ve evlenmeden önce hangi konularda eğitim almak istedikleri konusunda görüşlerini almaktır. Araştırma gereği, Ankara'da farklı üniversitelerde öğrenim görmekte olan 366 (210 kız, 156 erkek) öğrenciye ulaşılmıştır. Bilgi toplama araçları olarak araştırmacı tarafından oluşturulan kişisel bilgi formu ve yarı yapılandırılmış görüşme formu kullanılmıştır. Elde edilen veriler, içerik analizi yöntemi ile değerlendirilmiştir. Öğrencilerin ilişkilerinde en fazla problem yaşadıkları alanların sırasıyla iletişim (126; \% 34,05), çatışma çözme $(92 ; \%$ 24,86), farklılıkları kabul (74; \% 20), romantizmcinsellik (44; \% 11,90), sosyal destek $(34 ; \%$ 9,19) olduğu görülmektedir. Öğrencilerin en fazla problem yaşayacaklarını düşündükleri alanların sırasıyla romantizm- cinsellik $(129 ; \%$ 32,82), farklılıkları kabul (105; \% 26,72), iletişim (84; \% 21,37), çatışma çözme $(48 ; \% 12,22)$, sosyal destek $(27 ; \% 6,87)$ olduğu görülmektedir. Öğrencilerin en fazla eğitim almak istedikleri alanlarınsa sırasıyla iletişim (134; \% 38,51), çatışma çözme (92; \% 26,44), farklılıkları kabul $(62 ; \% 17,82)$, romantizm-cinsellik $(36 ; \% 10,34)$ ve sosyal destek $(24 ; \% 6,89)$ olduğu görülmektedir.

Anahtar kelimeler: Evlilik öncesi eğitim, evliliğe hazırlık programı, çift ilişkileri

\footnotetext{
* Bu çalışma danışmanlığını Prof. Dr. İbrahim Yıldırım'ın yaptığı “Evliliğe Hazırlık Programının Çift İlişkileri ve İlişki İstikrarı Üzerindeki Etkisi” adlı doktora tezinin bir bölümüdür.

** Ar. Gör., Hacettepe Üniversitesi Eğitim Fakültesi, haskan@ hacettepe.edu.tr
} 


\title{
Problems, University Students Experience In Their Relationship And Topics They Want To Be Educated On Before Marriage
}

\begin{abstract}
The objective of this study is to receive the opinions of university students on the areas they experience problems in their relationship, areas they expect to encounter problems during marriage and the issues they request training before marriage. For the purposes of the study, 366 students (210 female, 156 male) from different universities located in Ankara were included in the scope. The personal information form and semi-structured interview form developed by the researcher were used as the data collection instruments of the study. The data were analyzed by use of content analysis method. It was seen as a result of the analyzes conducted that the most important areas of problems for the students were communication (126; 34.05\%), conflict solving (92; 24.86\%), acceptance of differences $(74 ; 20.00 \%)$, romanticism-sexuality $(44 ; 11.90 \%)$ and social support $(34 ; 9.19 \%)$, while the areas they anticipated to experience problems were romanticism-sexuality $(129 ; 32.82 \%)$, acceptance of differences $(105 ; 26.72 \%)$, communication $(84 ; 21.37 \%)$, conflict solving $(48 ; 12.22 \%)$ and social support $(27 ; 6.87 \%)$. The subjects the students wanted to be educated on were understood to be communication $(134 ; 38.51 \%)$, conflict solving (92; $26.44 \%$ ), acceptance of differences (62; 17.82\%), romanticism-sexuality (36; $10.34 \%)$ and social support $(24 ; 6.89 \%)$.
\end{abstract}

Keywords: Premarital education, marriage preparation program, dyadic relationship 


\section{Giriş}

Üniversite dönemi pek çok birey için eş ve iş seçimi süreçlerini içeren, kritik bir dönemdir. Gençler üniversite yaşamı boyunca pek çok farklı fırsat ve olanaklarla karşılaşmakta, ileride eşleri olacak kişilerle tanışabilmektedirler. Genç yetişkinlik, yapısı itibariyle, romantik ilişkilerin ve çift olmanın ön plana çıktığı bir dönemdir. Bu dönem aynı zamanda, sağlıklı ilişki davranışları ve eş seçimine yönelmek için ideal bir dönemdir (Stover, 2008).

Partner ve eş seçiminin üniversite öğrencileri tarafından fazlasıyla önemsendiği gözlenmektedir. Üniversite öğrencileri üzerinde yapılan farklı araştırmalar öğrencilerin karşı cinsle ilişkilerinde sorunlar yaşadıklarını göstermektedir. Kılıç (1995) tarafından yapılan bir araştırmada, öğrencilerin \% 25'inin karşı cinsle ilişkilerinde problemler yaşadığı bulunmuştur. Türk Üniversite Gençliği Araştırmasının sonuçlarına göre de, üniversite öğrencilerinin \%10'u karşı cinsten arkadaşlarıyla ilişkilerinde sorunlar yaşamaktadırlar (Yazıcı, 2003). Gizir de (2005), üniversite öğrencileri üzerine yaptığı bir araştırmada, öğrencilerin \% 68'inin karşı cinsle ilişkiler anlamında çeşitli problemler yaşadıklarını bulgulamıştır. Benzer bir şekilde, üniversite öğrencilerinin romantik ilişki problemleri (\%28.4), arkadaşlık problemleri (\%22.5), cinsel problemler (\%27.8) yaşandığını gösteren bir başka araştırma da mevcuttur (Erkan, Özbay, Cihangir-Çankaya, Terzi, 2012). Topkaya ve Meydan'ın (2013) üniversite öğrencilerinin problem alanlarını taradıkları bir araştırmada da gençlerin en çok duygusal alanlarda (\% 26.3) ve romantik alanlarda (\% 42.8) sorunlar yaşadıkları ortaya çıkmıştır. Farklı oranların görüldüğü bulgulara karşın, ülkemizin farklı yerlerinde yapılmış araştırmaların hemen hepsinde, üniversite öğrencilerinin karşı cinsle ilişkilerinde önemli ölçüde sorun yaşadıkları anlaşılmaktadır.

Bu durum pek çok farklı sebepten kaynaklanıyor olabilir. Bireyler karşı cinsle kurdukları ilişkilerde, ileride karşılaşabilecekleri olası problemlerin bir kısmını yaşıyor olabilirler. Birbirlerini tanıma konusunda olumlu ve olumsuz yaşantılar geçiriyor olabilirler. Neticede bireyler kazandıkları deneyim ve geliştirdikleri ölçütlere göre eş seçimi yapabilmektedirler. Dolayısıyla eş seçiminden önceki arkadaşlık döneminin özenle sürdürülmesi ve iyi değerlendirilmesi gereken bir dönem olduğu söylenebilir (Özabac1, 2009).

Araştırmalar incelendiğinde, gençlerin aynı zamanda uzun soluklu bir ilişki içinde olmayı istedikleri anlaşılmaktadır. Keklik (2011) tarafından üniversite öğrencileriyle yapılan araştırmanın sonuçları, katılımcıların daha çok uzun süre devam edecek-olaysız bir evliliği kolaylaştıracak eş özelliklerini önemsemekte olduklarını göstermiştir. ABD'de yapılan kimi araştırmalar da bireylerin yaşam 
boyu sürecek bir evlilik arzu ettiklerini göstermektedir. Amerikalıların \%93'ü yaşamlarındaki en önemli amaçlarından biri olarak mutlu bir evlilik kurmayı ifade etmekte ve \%70'inden fazlası sıra dışı bir yaşam olayı ile karşılaşmamaları hâlinde evliliklerinin yaşam boyu süreceğine inandıkların belirtmektedirler (Waite ve Gallagher, 2000). Kültür ve millet fark etmeksizin insanlar sağlıklı ve kalıcı bir evlilik arayışı içindedirler (Ridley ve Sladeczek, 1992). Bununla beraber araştırmalar nüfusun \%20'sinin evlilik ile ilgili önemli sıkıntılar yaşadıklarını ve çiftlerin \%15'inin evliliklerinin ilk dört yılında ve \%70'ininse ise ilk on yılda ayrıldıklarını göstermektedir (Lebow, 2005). Amerika'da her türlü psikolojik danışma hizmetinden yararlanan insanlar içerisinde evlilik ilişkilerindeki sıkıntılardan ötürü yardım alanların oranı \% 40'tan fazladır (Gurman ve Fraenkel, 2002). Türkiye'de, Akademik Dayanışma Araştırma ve Geliştirme Vakfı-ADAG (2008) tarafından yapılan bir araştırmada, katılımcıların önemli bir kısmı $(\% 34,8)$ eşlerini baştan yanlış tanıdıklarını kısa bir süre sonra anladıklarını belirtmişlerdir. Aile ve Sosyal Araştırmalar Müdürlüğü-ASAGEM'in (2009) yürüttüğü araştırmada da boşanma ile evlilik öncesi dönem arasındaki ilişkiye işaret edilmektedir. Araştırmaya göre, boşanmış kadın ve erkeklerin evlilik öncesinde eşlerinde fark ettikleri olumsuz özelliklerin; psikososyal ve ekonomik temelli olumsuz kişilik özelliklerinin, evlilik sürecinde de çok önemli ve belirleyici olduğu ve boşanma sürecinde de etkili olmuş olabileceği düşünülmektedir.

$\mathrm{Bu}$ durum söz konusu evliliklerin eşler birbirlerini yeterince tanımadan gerçekleştiğini ve boşanma ile sonuçlandığını ortaya koymaktadır. Dolayısıyla eşlerin evlilik öncesi dönemi yeterince iyi değerlendirememiş olmalarının da boşanmalara yol açtığı düşünülebilir.

Çiftlerin boşanma noktasına aniden değil, belirli bir süreç içerisinde geldikleri düşünülmektedir. Sürerbiçer (2008) tarafından yürütülen araştırmada, boşanmış kişilerin yarıdan fazlasının (\%55,4), boşanmalarına neden olan hususları evlenmeden önce fark ettikleri görülmüştür. Dolayısıyla bireyler pek çok problemle evlilik öncesi dönemde yüz yüze gelmektedirler. Ancak bu noktada değişim ve gelişim süreci içine girmek yerine pek çok çift sorunları görmezden gelip evlendiklerinde yüzleşmek zorunda kalabilmektedirler. Bunun yerine, bireylerin ilişkilerinde yaşadıkları sorunları ele alarak, bu sorunların çözümüne odaklanmalarını sağlayacak evliliğe hazırlık programlarının yararlı olacağı düşünülmektedir.

Bu durumda psikolojik danışmanların, çift terapistlerinin, aile danışmanlarının, evlilik ve aile yaşamına ilişkin konuları değerlendirmek üzere gençlerle bir araya gelmeleri önem kazanmaktadır. Sevgi dolu uzun süreli ilişkileri kurmak ve sürdürmek için, gençlere bu konularda eğitim verilmesi oldukça önemlidir. 
Zira yapılan araştırmalarda gençler de evlilik için yeterli donanıma sahip olmadıklarını ifade etmektedirler (Martin, Specter, Martin ve Martin, 2003). Silliman ve Schumm'a (2004) göre, gençler de ilişkilere ve ilişkilerle ilgili eğitimlere ilgi içindedirler. Gençlerin \% 28.9'u evlilik öncesi programlar ve psiko-eğitimsel müdahaleler için olumsuz tutum gösterirken, \% 47.3'ü evlilikten ne beklediklerine ilişkin bir eğitime ihtiyaçları olduğunu belirtmektedirler (Martin vd., 2003). Araştırmalar, evlilik öncesi bir programa katılan ve tamamlayan çiftler arasında \%30 oranında daha az boşanma olduğunu göstermektedir (Stanley, Amato, Johnson ve Markman, 2006). Evlilik öncesi programlar hem eş adaylarını daha sağlıklı bir evliliğe hazırlayabilmeleri, hem de boşanmanın bireylere, ailelere ve topluma olan olumsuz ve maliyetli etkilerini önleyebilme açısından oldukça önemlidir (Carroll ve Doherty, 2003). Aynı zamanda, okul temelli evlilik öncesi eğitim programlarının manidar düzeyde olumlu etkileri olduğunu kanıtlayan araştırmalar da mevcuttur (Adler-Bader, Kerpelman, Schramm, Higginbotham, ve Paulk, 2007; Gardner, Giese ve Parrott, 2004).

Öğrencilerin eğitim almak istedikleri konularla, evliliğe hazırlık programlarının hedefleri de tutarlılık göstermektedir. Evlilik öncesi programların; (1) Çiftleri evlilik yaşamı hakkında bilgilendirmek, (2) Çiftlerin iletişim becerilerin artırma, (3) Çiftleri çatışma çözme becerileri edinme konusunda cesaretlendirme ve (4) çiftlerin para ve cinsellik gibi belirgin, hassas problem alanlarını konuşmalarına olanak sağlama gibi hedefleri vardır (Stahmann ve Hiebert, 1997). Benzer bir yaklaşıma göre, evliliğe hazırlık programlarının, bağlılıkla ilgili beklentileri değiştirme, ana-babalığa geçiş, bütçe oluşturma gibi konularda tartışma oluşturmak ve ilişkinin sağlıklı devam ettirilmesi için çiftlere iletişim ve çatışma çözme becerilerini öğretmek gibi amaçları olabilmektedir (Christensen ve Heavey, 1999). Evlilik öncesi programlar, çiftleri temel konular üzerinden geçerek sağlıklı bir evlilik kurmaları konusunda cesaretlendirir. Evlilik öncesi iletişim çiftlere, iletişim becerilerini geliştirme, ortak hedefler oluşturma, çatışmaları barışçıl yollarla çözme, gerçekçi beklentiler içinde olma konusunda yardımcı olabilmektedir (Banks, 2012). Evlilik öncesi programlar konusunda önemli araştırmaları olan Carroll ve Doherty'e (2003) göre bu tür programlar, evlilik yaşamındaki majör konulara temas etmesi bakımından önemlidir. Bu konular; çift iletişimi, çatışma çözme teknikleri, bağlılık, cinsel istek ve beklentiler, ekonomik yapı ve finansal yönetim ile ebeveynlik yaklaşımı şeklindedir.

Türkiye'de son yıllarda Aile ve Sosyal Politikalar Bakanlığı tarafından evlenmeyi planlayan çiftlere yönelik evliliğe hazırlık kursları bulunmakla beraber, doğrudan üniversite öğrencilerine yönelik evlilik öncesi program 
uygulamalarına rastlanmamaktadır. Psikolojik Danışma ve Rehberlik alanının hızla geliştiği $\mathrm{ABD}^{\prime}$ de pek çok üniversitenin (Florida State University, University of Iowa, University of Maryland, University of Notre Dame, University of Utah) psikolojik danışma merkezi incelendiğinde, öğrencilere sunulan hizmetler arasında "çiftlere yönelik psikolojik danışma" nın ayrıca yer aldığı görülmektedir. Türkiye'de de Bakanlığın yürüttüğü çalışmaların yanı sıra üniversite PDR Merkezlerinde bu tür hizmetlerin sunulması öğrenciler açısından ulaşılabilirliği artırabilir ve daha erken önlemler alma şansı sunabilir.

Türkiye'de PDR Merkezlerinin incelendiği bir araştırmada (Erkan, CihangirÇankaya, Terzi ve Özbay, 2011) merkezlere başvurma oranlarının \% 0.2 ile \% 8 (sadece bir merkez) arasında değiştiği görülmektedir. Başvuru oranlarının oldukça düşük olduğu görülmektedir. Ancak verilen hizmetler arasında, krize müdahale ve ilişki-evlilik/aile problemleri konusunda verilen yardımların başı çektiği görülmüştür.

Merkezlerin ortak bir örgüt yapısı içinde düzenlenmesi, personel ve donanım açısından güçlendirilmesi; ayrıca öğrencilerin ihtiyaç ve problemlerinin belirlenerek, bu çerçevede etkili müdahale yöntemlerinin ve hizmetlerinin sunulması gerektiği (Erkan, Cihangir-Çankaya, Terzi ve Özbay, 2011); ayrıca günümüz koşulları dikkate alınarak üniversite öğrencilerinin sürekli değişen ilgi, ihtiyaç ve beklentileri temelinde, üniversite PDR merkezlerinin rol ve işlevleri kapsamındaki hizmet ağını çeşitlendirerek geliştirmeleri önerilmektedir (Gizir, 2010). Öğrencilerin ilişkilerinde yaşadıkları problem alanlarının belirlenerek bu konularda eğitimler düzenlenmesi ve genel anlamda çiftlere yönelik psikolojik danışma hizmetleri sunulması yararlı olabilir.

Ülkemizde üniversite dönemi pek çok genç için evliliğe geçiş dönemi anlamına gelebildiği için, çiftlere yönelik psikolojik danışma hizmetlerinin ve evlilik öncesi eğitimlerin yaygınlaştırılması önemli görülmektedir. Ancak bunun öncesinde, çiftlerin eğitime ihtiyaç duydukları temel konuların belirlenmesi gerekmektedir. Türkiye'de konuyla ilgili olarak, çiftlere yönelik evlilik öncesi programların uygulandığı ve etkililiğinin sınandığı sınırlı sayıda araştırmaya rastlanmaktadır (Şen, 2009; Yılmaz ve Kalkan; 2010; Duran, 2010; Yalçın, 2010). Ancak çiftlerin evlilik öncesi eğitim ihtiyaçlarını belirlemeye yönelik olarak, Gaziantep ilinde yürütülmüş tek bir çalışmaya rastlanmaktadır (Hamamc1, Buğa ve Duran, 2011). Yapılan bu çalışmada ise, evlilik öncesi eğitim ihtiyaçların belirlemenin yanı sıra çiftlerin halihazırda ilişkilerinde problem yaşadıkları veya yaşayacaklarını düşündükleri alanların da belirlenmesi amaçlanmıştır. $\mathrm{Bu}$ nedenle bu çalışmada, evlilik planları olan üniversite öğrencilerinin romantik ilişkilerinde problem yaşadıkları alanlar; evlendikten 
Üniversite Öğrencilerinin Evlilik Öncesi İlişkilerde Problem Yaşadıkları ve Eğitim Almak İstedikleri Konular 285

sonra problem yaşayacaklarını düşündükleri alanlar ve evlenmeden önce hangi konularda eğitim almak istedikleri konuları araştırılmıştır.

\section{Yöntem}

$\mathrm{Bu}$ araştırmada üniversite öğrencilerinin romantik ilişkilerinde problem yaşadıkları alanları, evlendikten sonra problem yaşayacaklarını düşündükleri alanları ve evlenmeden önce eğitim almak istedikleri konuları incelemek amacıyla içerik analizi yöntemi kullanılmıştır. Cohen, Manion ve Morrison'a (2007) göre içerik analizi, eldeki yazılı bilgilerin temel içeriklerinin ve içerdikleri mesajların özetlenmesi ve belirtilmesi işlemi olarak da tanımlanmaktadır.

\section{Araştırmanın katılımcıları}

Araştırmanın katılımcılarına, elverişli örnekleme yöntemi ile ulaşılmıştır. Araştırmaya katılan bireylerin tamamı evlenmeyi planlayan üniversite öğrencilerinden seçilmiştir. Araştırma gereği, 210'u kadın, 156'sı erkek olmak üzere, toplam 366 üniversite öğrencisine ulaşılmıştır. Katılımcıların tamamı 1927 yaş aralığındadır. Ankara'da bulunan üç üniversitede öğrenim görmekte olan katılımcıların \% 24'ü Eğitim Fakültesinde, \% 21'i Edebiyat Fakültesinde, \% 19’u Fen Fakültesinde, \% 21'i Sağlık Bilimleri Fakültesinde ve \% 15’i Tıp Fakültesindedir.

\section{Veri toplama aracı}

Çiftlerin romantik ilişkilerine ve çift eğitimlerine ilişkin görüşlerini almak amacıyla araştırmacı tarafından oluşturulan Kişisel Bilgi Formu'nda katılımcılara cinsiyet, yaş, fakülte, öğrenim görülen üniversite gibi demografik bilgilere ilişkin sorular sorulmuştur. Yarı yapılandırılmış görüşme formunda ise, katılımcıların romantik ilişkilerinde yaşadıkları problemlerin; evlendikten sonra hangi konularda problem yaşayacaklarını düşündüklerinin ve evlenmeden önce hangi konularda eğitim almak istediklerine yönelik önerilerin belirtilmesini sağlayan üç açık uçlu soru yer almaktadır.

\section{Görüşme Formu}

Araştırma gereği hazırlanan yarı yapılandırılmış görüşme formunun iç geçerliğini sağlamak için görüşme formu PDR alanından üç uzmana sunulmuş ve geribildirimleri sonucunda forma son şekli verilmiştir. Nitel araştırmalarda iç geçerlik, araştırmacının ölçmek istediği veriyi, kullandığı araç ya da yöntemle gerçekten ölçüp ölçemeyeceğine ilişkindir (Yıldırım ve Şimşek, 2005). 
Ayrıca, bir başka uzmandan, verilerin kodlanması sürecinde görüş alınmış; kod ve temalar, diğer uzmanın belirlediği kod ve temalarla karşılaştırılmıştır. Kod ve temalarının uygunluğu arasındaki korelasyon hesaplanmıştır. Güvenilirliğin hesaplanmasında Miles ve Huberman (1994) tarafından önerilen "Güvenirlik= uzlaşma sayısı/uzlaşma+uzlaşmama sayısı" formülü kullanılmıştır. Böylece güvenilirlik \% 88 olarak bulunmuştur. Bu sonuca göre veri toplama aracının güvenilir olduğu söylenebilir. Görüşme formu uygulanmadan önce Hacettepe Üniversitesi Psikolojik Danışma ve Rehberlik bölümünden bir grup öğrenci ile pilot görüşmeler yapılmış ve soruların açık ve anlaşılır olup olmadığı teyit edilmiştir. Bu formda katılımcılara aşağıdaki sorular yöneltilmiştir:

1. "İlişkinizde hangi konularda problemler yaşıorsunuz?"

2. "Evliliğinizde hangi konularda problemler yaşayabileceğinizi düşünüyorsunuz?"

3. "Evlilik öncesinde hangi konularda eğitim almak isterdiniz?" soruları sorulmuştur.

Ayrıca katılımcı teyidi almak için görüşme formunun alt kısmına, bireylerin görüşmeye eklemek veya çıkarmak istedikleri konular olup olmadığı sorusu eklenmiş ve cevapları tekrar gözden geçirilmiştir.

\section{Verilerin analizi}

Verilerin analizinde içerik analizi kullanılmıştır. Öncelikle katılımcıların ifadeleri tekrar tekrar okunmuştur. Araştırmanın içerik analizinde açık uçlu sorulara ait her bir ifade araştırmanın analiz birimini oluşturmuştur. Yıldırım ve Şimşek'e (2006) göre toplanan verilerin önce kavramlaştırılması daha sonra da ortaya çıkan kavramlara göre mantıklı bir biçimde düzenlenmesi ve buna göre veriyi açıklayan temaların saptanması gerekmektedir. İçerik analizi sürecinde, Yıldırım ve Şimşek (2005) tarafından önerildiği gibi analiz birimleri, genel bir çerçeve içinde, araştırmacı tarafından birbirinden bağımsız olarak kodlanmıştır ve ortaya çıkan kodların ortak yönlerinden yola çıkılarak temalar belirlenmiş ve veriler kod ve temalara göre organize edilerek bulgular yorumlanmıştır.

İçerik analizi sürecinde, kodların ortak yönlerinden yola çıkılarak belirlenen beş tema şu şekildedir: "İletişim", "Çatışma çözme", "Romantizm-Cinsellik", "Sosyal Destek", "Farklılıkları Kabul". Alınan veriler buna göre organize edilerek bulgular araştırmacı tarafından yorumlanmıştır. Verilerin kodlanması sürecinde bağımsız uzman görüşü alınmış; kod ve temalar, farklı bir araştırmacının verileri inceleyerek belirlediği kod ve temalarla 
Üniversite Öğrencilerinin Evlilik Öncesi İlişkilerde Problem Yaşadıkları ve Eğitim Almak İstedikleri Konular 287

karşılaştırılmıştır. Kavramları isimlendirmede farklılıklar olmakla birlikte temalar literatüre göre temelde aynı anlama geldiği için değişiklik yapılmamıştır. Çalışmada ayrıntılı betimleme yapılmış ve bulgularda doğrudan alıntılara yer verilmeye çalışılmıştır.

\section{Bulgular}

$\mathrm{Bu}$ kısımda bulgular, evlenmeyi planlayan üniversite öğrencilerinin ilişkilerinde yaşadıkları problemler ve evlendiklerinde yaşayacaklarını düşündükleri problemler ve evlenmeden önce eğitim almak istedikleri konular biçiminde, açık uçlu üç soruya verilen yanıtlara göre düzenlenerek verilmiştir. Her başlık altındaki bulgular, İletişim, Çatışma Çözme, Romantizm-Cinsellik, Sosyal Destek, Farklılıkları Kabul olarak belirlenen temalara göre sunulmuştur. Kodlamalarda bir bireyin farklı temalar için belirttiği görüşler o temaların altında ayrı ayrı ele alındığı için ele alınan veri sayısı katılımcı sayısından fazla olabilmektedir.

\section{Öğrencilerin Romantik İlişkilerinde Yaşadıkları Problemlere İlişkin Bulgular}

Üniversite öğrencilerinin romantik ilişkilerinde yaşadıkları problemlere ilişkin değerlendirmeleri incelendiğinde öğrencilerin en fazla problem yaşadıkları alanların sırasıyla iletişim (126; \% 34,05), çatışma çözme $(92 ; \%$ 24,86), farkl11ıkları kabul (74; \% 20), romantizm-cinsellik (44; \% 11,90), sosyal destek $(34 ; \% 9,19)$ olduğu görülmektedir. Yüzdelerden anlaşılacağı üzere problem yaşanan alanlara ilişkin görüşlerin iletişim ve çatışma çözme boyutlarında yoğunlaştığı, sosyal destek boyutunun ise en son sirada yer aldığ gözlenmektedir.

Araştırmaya katılan bireylerin romantik ilişkilerinde yaşadıkları problemlere ilişkin ifadelerinden bazı örnekler şu şekildedir:

İletişim teması: "Bazı konuları konuşurken adeta birbirimizin bilerek içini acıtacak şekilde konuşuruz" (K94), "Kız arkadaşımın beni çocuk gibi azarlaması, sonra da özür diler ama iş işten geçmiş olur, işte yaşadı̆̆ımız sorun."(K36)

Çatışma çözme teması: "Aramızda yıllardır çözülemeyen ve çözülmedikçe düğ̈̈mlenen, ayrılacă̆ımızdan korktuğum sorunlarımız var" (K129), "Bazı insanlar nasıl çözüyorlar kavgaların anlamıyorum biz resmen birbirimizi incitiyor, hatta yıpratıyoruz"(K81), "Kavgalardan sonra barıştı̆̆ımızda adeta ilişkimize heyecan geldiği için mi çok kavga ediyoruz acaba"(K72).

Farklılıkları Kabul teması: "Partnerimle, birbirimizden ayr olarak arkadaşlarla zaman geçirme konusunda farklı düşünüyoruz. Ondan ayrı zaman geçirmeyi istememi yanlış buluyor" (K147), "Partnerim biraz değişse ve bana ayak 
uydursa çok mutlu olabiliriz ama aşır sabit fikirli, ona göre de ben değişmeliymişim" (K263).

Sosyal Destek teması: "Bazı en kötü anlarımda sevgilim değil arkadaşlarım yanımda oldu" (K93), "Genelde bir başarımı veya güzel bir şeyler giydiğimde hep arkadaşlarımdan övgü alıyorum, beni erkek arkadaşımın hiç takdir ettiği beğendiğ̈i olmaz, o kadar büyütülecek şeyler değil ki diyor"(K12).

Romantizm-Cinsellik temasi: "Ne zaman gerçekten sicaklık hissetsek, birbirimize yakınlaşsak sanki ayıp bir şey yapıyormuşuz gibi utanıp uzaklaşıyoruz" (K32), "sevgilim yan yana yürürken, bir yere girerken şöyle sahiplenerek elimi bile tutmaz"(K192).

\section{Öğrencilerin Evliliklerinde Yaşayacaklarını Düşündükleri Problemlere İlişkin Bulgular}

Üniversite öğrencilerinin evliliklerinde yaşayacaklarını düşündükleri problemlere ilişkin değerlendirmeleri incelendiğinde öğrencilerin en fazla problem yaşayacaklarını düşündükleri alanların sırasıyla romantizm- cinsellik (129; \% 32,82), farklılıkları kabul (105; \% 26,72), iletişim (84; \% 21,37), çatışma çözme $(48 ; \%$ 12,22), sosyal destek $(27 ; \%$ 6,87) olduğu görülmektedir. Yüzdelerden anlaşılacağı üzere problem yaşanacağı düşünülen alanlara ilişkin görüşlerin romantizm-cinsellik ile farklılıkları kabul boyutlarında yoğunlaştığı, sosyal destek boyutunun ise en son sırada yer aldığı gözlenmektedir.

Araştırmaya katılan bireylerin evliliklerinde yaşayacaklarını düşündükleri problemlere ilişkin ifadelerinden bazı örnekler şu şekildedir:

Romantizm-cinsellik teması: "Evlenince nasılsa artık evliyiz diyip ilişkimizde romantizmin, cinselliğin bitmesinden endişeliyim" (K8), "Cinsel konularda beni yetersiz bulur mu diye kaygiliyı" (K83).

Farklılıkları kabul teması: "Illeride ailelerimizin kültürel farklılıları ortaya çıkınca kavgalar olacağından korkuyorum" (K236), "Giyim kuşam, düşünce biçimi, insanlara bakış, hatta siyasi görüşlerimiz bile apayrı, acaba ileride sorun olur mu, değişebilir miyiz diye ümidim var ama ya olmazsa..." (K38).

İletişim teması: "Şimdi uzaktan telefonda bile kötü bir olay olsa bağırıyoruz birbirimize, evlenince nasıl olur konuşmalarımı bilmiyorum" (K62), "Bir hata yaptı̆̆ımda partnerim beni sevgisizlikle suçlar, oysa ben onu sevdiğim halde anlatamam, birbirimizi hep yanlış anlarız. İleride bu yanlış anlaşılmalar daha da artar mı diye kaygılıyım" (K39).

Çatışma Çözme teması: "Bu kavgalar çözümlenmezse ya evlenip boşanırsak diye kararsızllk içindeyim"(K211), "Bir kere herkesin içinde dikkat çekecek şekilde kavga ettik ve çözemedik, ama ben çok korktum. Aynı evin içinde olsak kötü şeyler yapar miyız iyice saldırganlık falan olur mu diye aklımdan geçiyor."(K302) 
Üniversite Öğrencilerinin Evlilik Öncesi İlişkilerde Problem Yaşadıkları ve Eğitim Almak İstedikleri Konular

Sosyal Destek teması: "Erkek arkadaşım bazen yurtdışında çalışıyor; ileride evde çocuklarımla bir başıma kalır mıyım, nasıl baş ederim diye düşünüp karamsarlı̆̆a kapıldığım anlar oluyor" (K30). "Bazı kötü anlarımda beni anlayamadiğı, üzüldüğüme anlam veremediği oluyor, acaba ileride iyice duygusuzlaşır $m \imath$ diye düşünüyorum"(K119).

\section{Öğrencilerin Evlilik Öncesinde Eğitim Almak İstedikleri Konulara İlişkin Bulgular}

Üniversite öğrencilerinin evlilik öncesinde eğitim almak istedikleri konulara ilişkin değerlendirmeleri incelendiğinde öğrencilerin en fazla eğitim almak istedikleri alanların sırasıyla iletişim (134; \% 38,51), çatışma çözme (92; \% 26,44), farklılıkları kabul $(62 ; \% 17,82)$, romantizm-cinsellik $(36 ; \% 10,34)$ ve sosyal destek (24; \% 6,89) olduğu görülmektedir. Yüzdelerden anlaş1lacağ1 üzere öğrencilerin evlilik öncesinde eğitim almak istedikleri konulara ilişkin görüşlerin iletişim ve çatışma çözme boyutlarında yoğunlaştığı, sosyal destek boyutunun ise en son sırada yer aldığı gözlenmektedir.

Araştırmaya katılan bireyler, evlilik öncesinde hangi konularda eğitim almak istediklerine ilişkin beş farklı tema için beklentilerini belirtmişlerdir:

İletişim teması: "Daha doğru ve să̆lıkl bir iletişim konusunda" (K18), "Birbirimizle düzgün konuşabilmemizle ilgili"(K80).

Çatışma çözme teması: "Kavgaları nasıl çözeceğimiz konusunda bir şeyler öğrenmemizi ve artık ona göre davranmak için söz vermemizi isterdim" (K53), "A ramızdaki problemlerin nasıl çözülebileceğini öğrenmek danışmak isterdim"(K4).

Romantizm- cinsellik: "Cinsellikle ilgili merak ettiğim bazı konularda internet yerine bir uzmandan bilgi almak isterdim" (K208), "Gerçek yakınlık için sürprizler mi, mutlu anlar yaratmak mi, aramızdaki aşkı taze tutacak şeyleri öğrenmek isterdim"(K45).

Farklılıkları Kabul teması: "Anlaşabilmek için birbirimizle her konuda aynı olmamız gerekmediğini bir de bir uzmanın açılı̆̆a kavuşturmasını isterdim" (K18), "Birbirimizden farkl yetişme tarzımıza ră̆men bir arada birbirimizi yargılamadan nasıl yaşayabileceğimizle ilgili bir uzmandan bilgi almak isterdim"(K116)

Sosyal Destek teması: "Zor günleri, birbirimizi yıpratmadan, birbirimizle dayanışma içinde nasıl aşarız konusunda deneyimli birilerinden bilgi edinmek isterdim" (K175), "hiç yapamıyorsun demek yerine, birbirimizi cesaretlendirme, başarabilirsin gibi şeyler söyleme, destekleme konularında asıl kız arkadaşımın, (tabi benim de) eğitimden geçmesini isterdim."(K287).

\section{Tartışma ve Sonuç}


$\mathrm{Bu}$ kısımda bulgular kısmına dayalı olarak tartışma ve yorum yapılmıştır. $\mathrm{Bu}$ amaçla önce evlenmeyi planlayan üniversite öğrencilerinin ilişkilerinde yaşadıkları problemlere, ardından evlendiklerinde yaşayacaklarını düşündükleri problemlere ve son olarak evlenmeden önce eğitim almak istedikleri konulara ilişkin bulguların tartışma ve yorumuna yer verilmiştir.

\section{Öğrencilerin Romantik İlişkilerinde Yaşadıkları Problemlere İlişkin Bulguların Tartışma ve Yorumu}

Üniversite öğrencilerinin romantik ilişkilerinde yaşadıkları problemlere ilişkin değerlendirmeleri incelendiğinde öğrencilerin en fazla problem yaşadıkları alanların sırasıyla iletişim, çatışma çözme, farklılıkları kabul, romantizmcinsellik, sosyal destek olduğu görülmektedir. Katılımcıların problem yaşanan alanlara ilişkin görüşlerin iletişim ve çatışma çözme boyutlarında yoğunlaştı̆̆ı görülmektedir.

Markman, Floyd, Stanley ve Storaasli'nin (1988) belirttiğine göre, gelecekte evliliklerde sürdürülecek iletişimi tahmin edebilmek, çiftlerin hâlihazırda birbirlerini ne kadar çok sevdiklerini değil de çatışmaları ve anlaşmazlıkları nasıl ele aldıkları ve çözmeye çalıştıklarını inceleyerek mümkün olabilmektedir. Noller ve Feeney'e (2002) göre, çiftlerin evlilik öncesi iletişimlerinin kalitesi, evlilik doyumu üzerinde doğrudan etkili faktörler arasındadır. Yapılan çalışmalarda çiftlerin evliliklerini değerlendirirken, demografik ve kişisel değişkenlerden ziyade, eşlerin aralarındaki günlük etkileşimi göz önünde bulundurdukları görülmektedir. Ayrıca evlilik problemleri olan çiftlerin ilişkilerinde çok daha fazla çatışma yaşadıkları anlaşılmaktadır. İliş̧i doyumunun yaşanan çatışmaların sıklığıyla da ilgili olduğu görülmektedir. Çiftlerin yaşadıkları fikir ayrılıklarının yarattığı gerilim ilişkinin diğer boyutlarına da taşınmaktadır. Evlilik öncesinde yaşanan çatışmaların sıklığı, evlilikteki çatışmalar ve ilişki doyumunun olmaması üzerinde belirleyicidir. Eşlerden birinin tartışmaya meyilliyken diğerinin çatışmayla başa çıkma tarzı olarak sürekli tartışmadan kaçınan bir tavır sergilemesi, çiftlerin karşılıklı olarak sevgilerini dışa vurmayan bir tavırlarının olması gibi etmenler de evlilik doyumunu azaltan etmenler arasında yer almaktadır (Noller ve Feeney, 2002).

Literatürde sıklıkla iletişimle ilgili güçlüklerin çatışma ile güçlükleri de beraberinde getirdiğine işaret edilmektedir. Bray'e (1995) göre çiftler arasında iletişim problemlerinin varlığı, çatışma ve etkili olmayan çatışma çözme yöntemlerini de beraberinde getirmektedir. Çatışmaların sık olması çiftin birbiriyle olumsuz etkileşimine neden olmakta; dolayısıyla anlaşmazlık ve uyumsuzlukları arttırmaktadır. Aile içi çatışma konusunda gerçekleştirilen ilk araştırmalar, çatışmanın aile fonksiyonlarına zarar verdiğini ortaya koyarken; 
son yıllarda yapılan araştırmalar, sıklıkla çatışma eğiliminde olan ancak çatışmalarını çözmeyi başarabilen çiftlerin evlilik doyumlarının, çatışmadan kaçınan çiftlerden çok daha yüksek olduğunu ortaya koymaktadır. Araştırma sonuçlarından yola çıkarak çiftlerin daha az çatışmalarının değil; çatışmayı yönetebilmelerinin ilişkiyi daha olumlu etkileyeceği sonucuna varılabilir. Bu noktada yine, çiftlere çatışma çözme becerilerinin ve çatışma yönetiminin kazandırılacağı eğitimlerin gerekliliği ortaya çıkmaktadır.

Üniversite öğrencilerinin ilişkilerinde en az problem yaşadıkları alanlar "sosyal destek" ve "romantizm-cinsellik" olarak ifade edilmiştir. Türkiye'de yapılan başka bir çalışmada da (Erkan, Özbay, Cihangir-Çankaya ve Terzi, 2012) üniversite öğrencilerinin en çok duygusal ve akademik sorunlar, en az ise madde kullanım ve cinsel problem yaşadıkları bulunmuştur. Ancak bu bulgular farklı bir noktaya da işaret ediyor olabilir. Toplulukçu bir kültürün üyeleri olarak, Türkiye'de bireylerin birbirlerine sosyal destek sunmayı ön planda tuttukları ve bu konuda partnerlerin birbirlerini yeterli düzeyde tatmin ettikleri düşünülebilir. Ancak romantizm-cinsellik konusunda problemlerin daha az ifade ediliyor olması, problemlerin yokluğuna değil de, kültürel bakımdan bu konuların daha az paylaşıldığına işaret ediyor olabilir. Bireyler bu tür problemleri ele almak ve bir araştırma kapsamında ifade etmek konusunda çekimser davranıyor olabilirler; romantizm- cinsellik konularında konuşmayı bir tabu olarak görüyor olabilirler. Evlilik öncesi dönemde çiftler, kendi aralarında da bu konuda daha sınırlı paylaşımda bulundukları için daha az sorun yaşıyor gibi görünebilirler. Türk üniversite öğrencilerinin sağlık riskleriyle ilgili yapılan bir çalışma, öğrencilerin yalnızca \% 25'inin cinsel ilişki yaşadığını göstermektedir (Hızel Bülbül, Sanlı, Fidan, Agar ve Ceyhun, 2008). Öğrencilerin duygusal bir ilişkiyi cinsel boyuta taşıma ihtimallerinin oldukça düşük olması; evlilik bağı dişında cinselliği engelleyerek bekarete anlam yükleyen ataerkil yapının varlığı (Cindoğlu, 1997) ele alınan sonuçlara yol açıyor olabilir.

\section{Öğrencilerin Evliliklerinde Yaşayacaklarını Düşündükleri Problemlere İlişkin Bulguların Tartışma ve Yorumu}

Üniversite öğrencilerinin evliliklerinde yaşayacaklarını düşündükleri problemlere ilişkin değerlendirmeleri incelendiğinde öğrencilerin en fazla problem yaşayacaklarını düşündükleri alanların sırasıyla romantizm- cinsellik, farklılıkları kabul, iletişim, çatışma çözme, sosyal destek olduğu görülmektedir. Katılımcıların en fazla problem yaşayabileceklerini düşündükleri alanların romantizm-cinsellik ile farklılıkları kabul boyutlarında yoğunlaştığı, sosyal destek boyutunun ise en son sırada yer aldığ1 gözlenmektedir. 
Katılımcıların evliliklerinde yaşayacaklarını düşündükleri problemler, araştırmalarda boşanma sebepleri arasında da görülebilmektedir. Abalı'nın (2006) Sakarya Adliyesi 1. ve 2. Aile Mahkemesine boşanmak için başvuran toplam 150 gönüllü kadın üzerinde yapmış olduğu araştırmada; katılımcıların kendi evliliklerindeki cinselliklerini boşanma nedeni olarak görme oranlarının \%15,3 olduğu, buna karşın kendileri dışındaki evliliklerde cinselliği boşanma nedeni olarak görme oranlarının \% 92,7 olduğu ortaya çıkmış, ayrıca eşleriyle mutlu bir cinsel ilişkileri olduğunu ifade eden katılımcı olmamıştır. ADAG tarafından gerçekleştirilen Boşanma Sebepleri araştırmasında, cinsel isteklerdeki farklılık ve farklılıkların getirdiği uyumsuzluğun (genel mizaç uyumsuzluğu, tüketim anlayışı farkı, cinsel isteklerdeki farklılık, eğlenme anlayışı farkı, dini yaşayış farkı, siyasi anlayış farkı, beslenme anlayışı farkı ve diğer) önemli boşanma sebepleri arasında yer aldığı belirtilmektedir.

Özkan da (1989) “Türkiye'de Boşanmaların Sebep ve Sonuçları" adlı araştırmasında boşanma sebeplerini; ekonomik durum farklılığından, yaş farklılığından, daimi ikametgâh farklılığından, eğitim seviyesi farklılığından, hayat üslubu farklılığından ve meslek farklılığından doğanlar olmak üzere altı grupta değerlendirmiştir. Özkan, eşlerin birbirlerine gereken önemi vermemeleri ve birbirlerini oldukları gibi kabul etmemelerini önemli boşanma sebepleri arasında belirtmektedir. Arıkan da (1996) "Halkın Boşanmaya İlişkin Tutumları" adlı araştırmada; eşlerin yetişme tarzlarının, dini inançlarının ve eğitim durumlarının birbirinden çok farklı olmasının, evlilikleri boşanma tehlikesiyle karşı karşıya bırakan durumlar olduğunu ortaya koymuştur. Eşler arasındaki eğitim düzeyi farkı ve sosyo-kültürel farklılıkların boşanma sebepleri arasında olduğunu gösteren pek çok araştırma bulunmaktadır (ADAG, 2008; Özkan, 1989; Yıldırım, 2004).

Önceki araştırma bulgusu ile birlikte ele alındığında, bu soruya verilen yanıtlar romantizm-cinsellik alanında problem yaşadıklarını ifade etmeseler de çiftlerin, evlendiklerinde bu konuda problem yaşayacaklarını düşündüklerini göstermektedir. Bu durum daha önce sözü edildiği gibi, çiftlerin bu konuda daha az paylaşımda bulunmalarından kaynaklanıyor olabilir. Hızel Bülbül ve diğerlerinin (2008) yaptıkları araştırmada üniversite öğrencilerinin çok az bir kısminın cinsel ilişkide bulunuyor olduğu yönündeki ve Türkaslan ve Yurtkuran-Demirkan'ın (2007) yaptıkları araştırmada türk öğrencilerin önemli bir çoğunluğunun evlilik dişı beraberliğe sıcak bakmadıkları yönündeki bulguları dikkate alındığında, çiftlerin henüz deneyim sahibi olmadıkları bir konuda "kaygılı" hissediyor oldukları düşünülebilir. Keklik (2011) tarafından üniversite öğrencileri ile yürütülen araştırmada bütün katılımcıların ileride evleneceklerini belirtmeleri cinsiyet ilişkilerini yaşamanın evlilik içerisinde ele alındığına ilişkin bir bulgu olarak nitelendirilmiştir. 
ASAGEM (2009) tarafından yapılan boşanma nedenleri araştırmasında da çocuk bakımı ve yetiştirilmesi konusunda düşüncelerin farklı olmasını boşanma nedenleri arasında ifade edenlerin oranı \%34; örf, adet ve din açısından anlaşamıyor olmayı ifade edenlerin oranı \%19, eşin "istediğim gibi ol" diyerek baskı yapmasını ifade edenlerin oranı \%34 olarak bulunmuştur. Birbirlerinin farklılıklarını olduğu gibi kabul edebiliyor olsalar bile gençler, evlilik gibi formal bir ilişki içerisine girdiklerinde, eşlerinde var olan farklılıkların aileleri ve toplum tarafından onaylanmayacaklarını düşünüyor olabilirler. Toplulukçu kültürler arasında yer alan türk toplumunda aile görüşleri bireyin görüşleri üzerinde etkili olup, aileden onay almanın fazlasıyla önemsendiği düşünülebilir. ASAGEM'in (2009) yürüttüğü boşanma nedenleri araştırmasında, "Evliliğiniz süresince aileniz eşinizi size uygun buldu mu?" sorusuna katılımcıların \%20'si hayır cevabı verirken; “Uygun bulmadı ama kabul etmek zorunda kaldı" diyenlerle birlikte boşanılan eşin ailesi tarafından kabul görmediğini belirtenlerin oranı yaklaşık \%40 olarak bulunmuştur. Aileler de ilişkiye dahil olduğunda ilişkinin niteliği değişebilmektedir. Aynı araştırmada, eşlerinin, ailesinin yanında kendisine tek başına oldukları zamanlara göre farklı davrandığını ifade edenlerin oranı kadınlarda \% 40, erkeklerde \% 33 olarak bulunmuştur.

Öğrencilerin problem yaşayacaklarını düşündükleri alanların genelde boşanma sebepleri arasında yer alıyor olması bireylerin ilişkilerinde yaşayabilecekleri bazı sorunları önceden tahmin edebildiklerini göstermektedir. Bu bilgiler psikolojik danışma ve rehberliğin önleyici rolü açısından anlamlıdır; zira ilişkilerde yaşanabilecek sorunlar tahmin edilebildiği ölçüde bu sorunları henüz evlenmeden önleyebilecek çalışmalar düzenlenebilir.

Özellikle farklılıkları kabul konusunun evlilik öncesinde ele alınmasının bir yararı daha vardır. Gladding (2012) çiftlerin ilk yıllarının boşanma olasılıklarının en yüksek olduğu zamanlardan biri olduğunu ifade etmektedir. Çünkü bu dönem eşlerin aralarındaki farklılıkları çözümlemeye çalıştıkları zamandır. Genel olarak yeni bir çiftin yaşam döngüsü daha çok uyum sağlama ve adaptasyonun egemen olduğu bir dönemdir. Örneğin, yeni eşler mekanı, öğünleri, boş zamanları, uyuma zamanını ve işe ayırdıkları zamanı paylaşmanın ve birbirleriyle uyumlu bir şekilde ayarlamanın çabası içerisinde olurlar. Birbirlerinin dilekleri, ricaları ve fantezilerine uygun davranmaya çalışmak durumundadırlar. Bu, zaman alan bir süreçtir ve iyi niyet, enerji ve uzlaşmayı gerektirir. Dolayısıyla, çiftlerin evlilik öncesinde, bu zorlu süreçten önce birbirlerinin farklılıklarını kabul etmeyi öğrenmeleri oldukça önemlidir. 
Farklılıkları kabul edebilmek aynı zamanda saygının da göstergesidir; bir bireyin kendinden başka olanı olduğu gibi kabul ederek onun özüne saygı duyması, kendi oluşuna destek olmasıdır. Partnerlerin bireysel farklılıklarını görmeye açık olmamalarının, birinin diğerini kendine benzetme çabalarına yol açabildiği ve bunun da hayal kırıklı̆̆ı ve çatışma doğurabildiği ifade edilmektedir (Keitner, Heru ve Glick, 2010). Buna göre, evlilik öncesi dönemde çiftlere, birbirlerinin farklılıklarını fark etmeleri ve kabul etmeleri konusunda yardımcı olunmalıdır.

\section{Öğrencilerin Evlilik Öncesinde Eğitim Almak İstedikleri Konulara İlişkin Bulguların Tartışma ve Yorumu}

Üniversite öğrencilerinin evlilik öncesinde eğitim almak istedikleri konulara ilişkin değerlendirmeleri incelendiğinde öğrencilerin en fazla eğitim almak istedikleri alanların sırasıyla iletişim, çatışma çözme, farklılıkları kabul, romantizm-cinsellik ve sosyal destek olduğu görülmektedir. Öğrencilerin evlilik öncesinde eğitim almak istedikleri konulara ilişkin görüşlerin iletişim ve çatışma çözme boyutlarında yoğunlaştığı görülmektedir.

Geçmiş yıllarda yapılmış araştırmalar incelendiğinde; ilişki eğitimi ve evlilik öncesi programların; çift uyumunu, partnerin farklılıklarını kabulü, iletişimi güçlendirme ve problem çözme becerilerini artırdığı; uyumsuzluğu, olumsuz duyguları ve boşanmayı azalttığı ve bu yolla evlilik kalitesini ve istikrarını da yükselttiği görülmektedir (Markman ve Hahlweg, 1993; Markman, Renick, Floyd, Stanley ve Clements, 1993; Markman, Stanley ve Blumberg, 2001). Carroll ve Doherty (2003) evlilik öncesi programların etkililiği konusunda 1965 ile 2001 yılları arasında yapılmış araştırmalara ilişkin bir meta analitik çalışma yapmışlardır. $\mathrm{Bu}$ araştırmalardan 16'sında, evliliğe hazırlık programının katılımcılarında iletişim, problem çözme, empati gibi kişiler arası becerilerde manidar bir farklılık bulgulanmıştır. Araştırmalardan 11'inde, katılımcıların puanları kontrol grubundakilerden anlamlı olarak daha iyi olduğu; 5 'inde ise çiftlerin bu tür bir programa katılma deneyimini yardımcı olarak gördükleri ifade edilmiştir. Carroll ve Doherty, ortalama olarak, evliliğe hazırlık programlarına katılanların, programa katılmayanların \%79'undan daha iyi durumda oldukları ve bu etkinin altı aydan üç yıla kadar sürdüğünü belirtmişlerdir.

Türkiye'de de belediyeler tarafından ve üniversitelerde araştırmacılar tarafından düzenlenen evlilik öncesi eğitimlerin etkili olabildiği görülmektedir (Yilmaz ve Kalkan, 2010; Duran, 2010; Yalçın, 2010). 2008 yılında, Çankaya Belediyesi Evlendirme Birimine başvuran gönüllü 62 çifte verilen "Evlilik Öncesi Çift Eğitimi" sonucunda, çiftlerin birbirlerini anlayışlı bir şekilde 
dinleyebildikleri (\% 75), birbirlerinin gerçekten ne söylemeye çalıştığını anladıkları (\% 68), problemlerini konuşarak çözdükleri (\% 75,8), nişanlıları ile önemli konuları konuşmaya çekinmedikleri (\% 82,3) ve doğru iletişim kalıplarını kullandıkları (\% 75) bulunmuştur (Şen, 2009). Yapılan araştırmalar genel olarak, evliliğe hazırlık programlarının çiftlerin iletişim becerileri ve çatışma çözme becerileri üzerinde olumlu etkilerinin olduğunu göstermektedir. Ayrıca, Ridley ve Sladeczek'in (1992) Guerney'in ilişki geliştirme programını kullanarak yaptıkları araştırmada, deney ve kontrol grubu arasında birbirini kabul konusunda deney grubu lehine anlamlı farklılıklar olduğu ortaya koyulmuştur. Görüldüğü gibi evliliğe hazırlık programları farklılıkları kabul konusunda da çiftleri olumlu etkileyebilmektedir.

Bireylerin, kimi sorunların evlenince azalacağını veya partnerin nasılsa değişeceğini düşünmesinin akılcı olmadığı ve bu düşünce biçiminin bireyleri hayal kırıklığına uğrattığı açıktır. Dolayısıyla bireylerin evlenmeden önce sorun yaşayabilecekleri konularda farkındalık kazanmalarını sağlamak ve evlilikle ilgili temel konularda bilgi edinmelerini sağlayarak evliliğe hazır olmalarına yardımcı olmak son derece önemli görülmektedir.

\section{Öneriler}

$\mathrm{Bu}$ çalışmanın sonuçlarından yararlanılarak evlilik öncesi eğitimler düzenlenebilir. Araştırmacılar, öğrencilerin problem yaşadıkları, problem yaşayacaklarını düşündükleri ve eğitim almak istedikleri konuları dikkate alarak evliliğe hazırlık programları geliştirebilirler. Ayrıca bu çalışma genişletilerek Türkiye'de çiftlerin problem yaşadıkları alanlar ve evlilik öncesi eğitim ihtiyaçları belirlenebilir. Bu yolla, bireylere standart birtakım konular yerine, ihtiyaç duydukları alanlarda eğitim sunulması sağlanmış olur. Böylece çiftlerin yaşadıkları problemler daha fazla büyümeden ve çiftler evlilik aşamasına gelmeden önlenebilir. 


\section{Kaynakça}

Abalı, S. (2006). Boşanmak için başvuran kadınlarm evlilikteki cinsel yaşamlarım boşanma nedeni olarak görme durumları. (Yayımlanmamış yüksek lisans tezi). Marmara Üniversitesi, Sağlık Bilimleri Enstitüsü, İstanbul.

Adler-Baeder, F., Kerpelman, J., Schramm, D. G., Higginbotham, B. ve Paulk, A. (2007). The Impact of Relationship Education on Adolescents of Diverse Backgrounds. Family Relations, 56(3): 291-303.

ASAGEM (Aile ve Sosyal Araştırmalar Genel Müdürlüğü), (2009). Boşanma nedenleri araştırması. Ankara: Aile ve Sosyal Araştırmalar Genel Müdürlüğü.

ADAG (Akademik Dayanışma Araştırma ve Geliştirme Vakfı), (2008). Boşanma sebepleri araştırması. Ankara: Aile ve Sosyal Araştırmalar Genel Müdürlüğü.

Arıkan, Ç. (1996). Halkın Boşanmaya İlişkin Tutumları Araştırması. Başbakanlık Aile Araştırma Kurumu.

Banks, S.G. (2012). Using Choice Theory and Reality Therapy in Premarital Counseling. İçinde P. A. Robey, R. E. Wubbolding ve J. Carlson. (Eds.). Contemporary Issues in Couples Counseling. pp.211-225. New York: Routledge.

Bray, J. H. (1995). Intergenerational research in family therapy. American Association for Marriage and Family Therapy, New York: NY.

Carroll, J. S. ve Doherty, W. J. (2003). Evaluating effectiveness of premarital prevention programs: A meta-analytic review of outcome research. Family Relations, 52(2), 105-118.

Cindoğlu, D. (1997). Virginity Tests and Artificial Virginity in Modern Turkish Medicine. Women's Studies International Forum, 20(2), 253-261.

Cohen, L., Manion, L. ve Morrison, K. (2007). Research methods in education (6th ed.). New York, NY: Routledge.

Christensen, A. ve Heavey, C.L. (1999). Intervention for Couples. Annual Reviews Psychology, 50, 165-190.

Duran, Ş. (2010). Evlilik öncesi ilişki geliştirme programının romantik ilişkiler yaşayan üniversite öğrencilerinin iletişim becerileri, çatışma iletişim tarzları ve ilişki istikrarlarn üzerine etkisinin incelenmesi. (Yayımlanmamış yüksek lisans tezi). Gaziantep Üniversitesi Sosyal Bilimler Enstitüsü, Gaziantep.

Erkan, S., Cihangir Çankaya, Z., Terzi, Ş. ve Özbay, Y. (2011). Üniversite Psikolojik Danışma ve Rehberlik Merkezlerinin İncelenmesi. Mehmet Akif Ersoy Üniversitesi Eğitim Fakültesi Dergisi, 11(22), 174- 198.

Erkan, S., Özbay, Y., Cihangir Çankaya, Z. ve Terzi, Ş. (2012). Üniversite öğrencilerinin yaşadıkları problemler ve psikolojik yardım arama gönüllükleri. Eğitim ve Bilim, 37(164), 94-107. 
Üniversite Öğrencilerinin Evlilik Öncesi İlişkilerde Problem Yaşadıkları ve Eğitim Almak İstedikleri Konular 297

Gardner, S.P., Giese, K. ve Parrott, S.M. (2004). Evaluation of the connections: Relationships and marriage curriculum. Family Relations, 53, 521-527.

Gizir, C. A. (2005). Orta Doğu Teknik Üniversitesi son sınıf öğrencilerinin problemleri üzerine bir çalışma. Mersin Üniversitesi Eğitim Fakültesi Dergisi, 1(2), 196-213.

Gizir, C. A. (2010). Üniversite Psikolojik Danışma ve Rehberlik Merkezleri'nin rol ve işlevleri: Gelişmeler ve sinırlılıklar. Mersin Üniversitesi Eğitim Fakültesi Dergisi, 6(2), 11-25.

Gladding, S.T. (2012). Aile terapisi. tarihi, kuram ve uygulamaları. İ. Keklik ve İ. Yıldırım (Çev. Ed.). Türk Psikolojik Danışma ve Rehberlik Derneği Yayınları: Ankara.

Gurman, A.S. ve Fraenkel, P. (2002). The history of couple therapy: A millennial review. Family Process, 41(2), 199-260.

Hamamc1, Z., Buğa, A. ve Duran, Ş. (2011). Üniversite öğrencilerinin evlilik yaşantısı ile ilgili bilgi kaynaklarının ve evlilik öncesi eğitim ihtiyaçlarının incelenmesi. Aile ve Toplum, 7(26), 33-51.

Hizel Bülbül, S., Sanli, C., Fidan, S., Agar, A. ve Ceyhun, G. (2008). Health risk behaviours of the students in an Anatolian university. Pediatrics, 121(1), 89.

Keitner, G.I., Heru A.M. ve Glick I.D. (2010). Clinical manual of couples and family therapy. Washington, DC: American Psychiatric Publishing, Inc.

Keklik, İ. (2011). Mate selection preferences of Turkish university students. Eğitim Araştırmaları-Eurasian Journal of Educational Research, 44, 129-148.

Kılıç, M. (1995). Üniversite öğrencilerinin ruh sağlığını bozan nedenler ve tedavide başvurdukları çözüm yolları. İnönü Üniversitesi Ĕ̆itim Bilimleri Dergisi, 2, 86-93.

Lebow, J. (2005). Marital distress. Family Therapy Magazine, May/June, 38-45.

Markman, H. J., Floyd, F. J., Stanley, S. M. ve Storaasli, R. D. (1988). Prevention of marital distress: A longitudinal investigation. Journal of Counseling and Clinical Psychology, 56(2): 210-217.

Markman, H. J. \& Hahlweg, K. (1993). The prediction and prevention of marital distress: An international perspective. Clinical Psychology Review,13, 29-43.

Markman, H.J., Renick, M.J., Floyd, F.J. Stanley, S. M. ve Clements, M. (1993). Preventing marital distress through communication and conflict management training: A 4-and 5-year follow-up. Journal of Consulting and Clinical Psychology, 61(1), 70-77.

Markman, H. J., Stanley, S. M. ve Blumberg, S. L. (2001). Fighting for your marriage: Positive steps for preventing divorce and preserving a lasting love (Rev. ed.). San Francisco: Jossey-Bass. 
Martin, P. D., Specter, G., Martin, M. ve Martin, D. (2003). Expressed attitudes of adolescents toward marriage and family life. Adolescence, 38(150), 359367.

Miles, M. B. ve Huberman, A. Michael. (1994). Qualitative data analysis: An expanded source book. Thousand Oaks, CA: Sage Publications.

Noller, P. ve Feeney, J. A. (2002). Communication, relationship concerns, and satisfaction in early marriage. A. Vangelisti, H. Reis and M. Fitzpatrick (Ed.), Stability and change in relationships in (pp. 129-155) UK: Cambridge University Press.

Özabacı, N. (2009). Evlilik öncesi ilişkiler. İçinde H. Yavuzer (Ed.). Evlilik Okulu. ss: 48-61. İstanbul: Remzi.

Özkan, Z. (1989). Türkiye'de boşanmaların sebep ve sonuçları. (Yayımlanmamış doktora tezi). İstanbul Üniversitesi Sosyal Bilimler Enstitüsü, İstanbul.

Ridley. C. A. ve Sladeczek, I. E. (1992). Premarital relationship enhancement: Its effects on needs to relate to others. Family Relations, 41, 148-153.

Silliman, B. ve Schumm, W. R. (2004). Adolescent perceptions of marriage and premarital couples education. Family Relations, 53, 513-520.

Stanley, S.M., Amato, P.R., Johnson, C.A. ve Markman, H.J. (2006). Premarital education, marital quality and marital stability: findings from a large, random household survey. Journal of Family Psychology, 20(1), 117-126.

Stahmann, R. F. \& Hiebert, W. J. (1997). Premarital counseling: The professional's handbook. New York: Lexington Books.

Stover, C. L. (2008). Adolescents attitudes towards counseling by demographic group: Before and after a youth relationship education curriculum. (Unpublished master thesis). Auburn University, Alabama.

Sürerbiçer, F. S. (2008) Boşanmıฺ̧ bireylerin deneyimlerine göre evlilik eğitimi gereksinimi. (Yayımlanmamış yüksek lisans tezi). Ankara Üniversitesi, Ankara.

Şen, B. (2009). Evlenmek üzere başvuruda bulunan bir grup nişanlı çiftin evlilik ve "evlilik öncesi çift eğitimi"ne ilişkin bilgi, görüş ve değerlendirmeleri. (Yayımlanmamış yüksek lisans tezi). Hacettepe Üniversitesi Sosyal Bilimler Enstitüsü, Ankara.

Topkaya, N. ve Meydan, B. (2013). Üniversite öğrencilerinin problem yaşadıkları alanlar, yardım kaynakları ve psikolojik yardım alma niyetleri. Trakya Üniversitesi Eğitim Fakültesi Dergisi, 3(1), 25-37.

Türkaslan, N. ve Yurtkuran-Demirkan, S. (2007). Üniversite son sinıf öğrencilerinin evliliğin kuruluşuna ilişkin görü̧s ve düşünceleri. Ankara: T.C. Başbakanlık Aile ve Sosyal Araştırmalar Genel Müdürlüğü Yayınları.

Waite, L. J. ve Gallagher, M. (2000). The case for marriage: Why married people are happier, healthier and better off financially. New York: Doubleday. 
Üniversite Öğrencilerinin Evlilik Öncesi İlişkilerde Problem Yaşadıkları ve Eğitim Almak İstedikleri Konular

Yalçın, İ. (2010). İlişki geliştirme programının üniversite öğrencilerinin ilişki doyum düzeylerine etkisi. (Doktora tezi). Hacettepe Üniversitesi Sosyal Bilimler Enstitüsü, Ankara.

Yazıcı, E. (2003). Türk üniversite gençliği araştırması. Ankara: Gazi Üniversitesi Yayınları.

Yıldırım, A. ve Şimşek, H. (2005). Sosyal bilimlerde nitel araştırma yöntemleri. (6. bask1). Ankara: Seçkin Yayıncılık.

Yıldırım, N. (2004). Türkiye'de boşanma ve sebepleri. Türk Dünyası Sosyal Bilimler Dergisi, 1(28), 59-81.

Yılmaz, T. ve Kalkan, M. (2010). Evlilik öncesi ilişki geliştirme programının çiftlerin ilişki doyumuna etkisi. Kuram ve Uygulamada Eğitim Bilimleri, 10(3), 1893-1920. 